\title{
Impact of Coordinated Pseudohalide Ions and Picolinamide on Supramolecular Synthons in Selected Zinc and Cadmium Complexes
}

\author{
Marijana Đaković, ${ }^{1, *}$ Jarosław Jaźwiński ${ }^{2}$ and Zora Popović ${ }^{1, *}$ \\ ${ }^{1}$ Department of Chemistry, Faculty of Science, University of Zagreb, Horvatovac 102a, HR-10000 Zagreb, Croatia \\ ${ }^{2}$ Institute of Organic Chemistry, Polish Academy of Sciencies, Kasprzaka 44, Warsaw 01-224, Poland \\ *Corresponding author: E-mail: mdjakovic@ chem.pmf.hr, zpopovic@chem.pmf.hr
}

Received: 14-10-2014

Dedicated to the memory of Prof. Dr. Jurij V. Brenčič.

\begin{abstract}
Four new $\mathrm{Zn}$ and $\mathrm{Cd}$ picolinamide (pia) complexes with cyanate and azide ions, namely $\left[\mathrm{Zn}(\mathrm{NCO})_{2}(\text { pia })_{2}\right](\mathbf{1})$, $\left[\mathrm{Cd}(\mathrm{NCO})_{2}(\mathrm{pia})\right]_{n}(\mathbf{2}),\left[\mathrm{Zn}\left(\mathrm{N}_{3}\right)_{2}(\mathrm{pia})_{2}\right](\mathbf{3})$ and $\left[\mathrm{Cd}\left(\mathrm{N}_{3}\right)_{2}(\mathrm{pia})\right]_{n} \cdot n \mathrm{H}_{2} \mathrm{O}(\mathbf{4})$, have been prepared and characterized by IR and NMR spectroscopy, and thermal (TG/DTA) methods. For the compounds $\mathbf{1}$ and $\mathbf{3}$ X-ray analysis revealed mononuclear molecular structure with octahedral $\mathrm{N}_{4} \mathrm{O}_{2}$ environment around the zinc(II) center with cis-arrangement of ligands. Only in $\mathbf{1}$ the amide head-to-head supramolecular motifs, represented by an $\mathrm{R}_{2}^{2}(8)$ designator, are observed, while in $\mathbf{3}$ none of the typical amide motifs were found.

While the IR data suggest the polymeric structures for $\mathbf{2}$ and $\mathbf{4}$ in the solid state, all the NMR spectral data support the monomeric structure of the compounds in the solution.
\end{abstract}

Keywords: Zinc(II) and cadmium(II) complexes; Picolinamide; Crystal structure; Supramolecular synthons; IR and NMR spectroscopy; Thermal analysis (TG/DTA).

\section{Introduction}

The reasons for combining metal ions and organic ligands into supramolecular coordination networks are countless; they give access to structural diversity and properties likewise adsorbtion of small molecules, targeted spectral and magnetic properties, conductivity and catalytic activity that are less common for organic solids. ${ }^{1-7}$ These applications depend on the material's structure and control of the synthesis is the crucial factor in the formation of new structures. The most important factors susceptible to change in the rational design of metal-organic frameworks are the $\mathrm{pH}$ value, solvent type, reaction temperature and time. ${ }^{8}$ In this context and in continuation of our earlier investigations, we undertook this research to implement more information for molecular recognition processes and relevance of the inter-ligand interactions on structure-properties-function relationship. Therefore, the usage of self-assembly of weaker intermolecular forces such as hydrogen bonds in creating large complex units via desirable motifs is a practical approach.

Recently, we have found for the amide moiety that in picolinamide (pyridine-2-carboxamide, pia) complexes it does not display its usual supramolecular behaviour, ${ }^{9,10}$ e.g. to build robust and reliable $\mathrm{R}_{2}^{2}(8)$ synthons as it is generally so in organic systems. Instead, it participates more often in the formation of tetrameric $\mathrm{R}_{4}^{2}(8)$ motifs involving other accessible hydrogen-bonding accepting atoms. For the thiocyanate complexes of $\mathrm{Co}(\mathrm{II}), \mathrm{Ni}$ (II) and $\mathrm{Cu}$ (II) with pia, the $\mathrm{R}_{4}^{2}(8)$ tetrameric motif was found as a synthon of choice, while for $\mathrm{Zn}$ (II) complexes both supramolecular motifs, $R_{2}^{2}(8)$ and $R_{4}^{2}(8)$, were observed. As a continuation of our attempts in determination of 'supramolecular conditions' at which the self-complementary amide motif is a reliable and robust supramolecular synthon, ${ }^{9-16}$ we opted for the other two pseudohalide ions, azide and cyanate, and in this paper we report on their impact on supramolecular synthon formation in picolinamide complexes of zinc and cadmium. 


\section{Experimental}

\section{1. Materials and Physical Measurements}

All chemicals were purchased from Aldrich Chemical Co. and were used as received without further purification. The $\mathrm{CHN}$ analyses were performed in a Perkin-Elmer 2400 Series II CHNS analyser in the Chemical Analytical Service Laboratories of the Ruđer Bošković Institute, Zagreb, Croatia. The IR spectra were obtained from KBr pellets in the range $4000-450 \mathrm{~cm}^{-1}$ with a Perkin-Elmer Spectrum RXI FT-spectrometer. Thermal measurements were carried out on a Mettler-Toledo TGA/SDTA $850^{\mathrm{e}}$ module in a sealed aluminium crucible $(40 \mu \mathrm{L})$. The compounds were heated in the nitrogen flow $(200 \mathrm{~mL} / \mathrm{min})$ at a rate of $10{ }^{\circ} \mathrm{C} / \mathrm{min}$. Data collection and analysis were performed using the programme package STAR Software $9.01 .{ }^{17}$ in the temperature range $25-600{ }^{\circ} \mathrm{C}$.

\section{2. Preparation of Complexes}

\section{2. 1. General procedure for (1)-(4)}

A warm aqueous solution of picolinamide $(25 \mathrm{~mL})$ was added dropwise with stirring to an aqueous solution of the corresponding metal nitrate $(10 \mathrm{~mL})$. An aqueous solution $(10 \mathrm{~mL})$ of sodium cyanate $(\mathbf{1}$ and $\mathbf{2})$ or sodium azide (3 and 4) was added into the resulting mixture. The obtained clear solution was then left at room temperature allowing slow evaporation until X-ray quality crystals were formed. The crystals were filtered off, washed with small portions of cold water and dried in air.

\section{2. 2. Preparation of $\left[\mathrm{Zn}(\mathrm{NCO})_{2}(\text { pia })_{2}\right]$}

Used: $\mathrm{Zn}\left(\mathrm{NO}_{3}\right)_{2} \cdot 6 \mathrm{H}_{2} \mathrm{O}(0.30 \mathrm{~g} ; 1 \mathrm{mmol})$, picolinamide (0.24 g; $2 \mathrm{mmol})$, sodium cyanate $(0.13 \mathrm{~g} ; 2 \mathrm{mmol})$. Yield: $58 \%(0.23 \mathrm{~g} ; 0.58 \mathrm{mmol})$. Anal. Calc. for $\mathrm{C}_{14} \mathrm{H}_{12} \mathrm{ZnN}_{6} \mathrm{O}_{4}: \mathrm{C}, 42.71 ; \mathrm{H}, 3.07 \mathrm{~N}, 21.35$. Found: $\mathrm{C}$, 43.16; H, 3.43; N, 21.73\%. FT-IR (Fig. S1) $\left(\mathrm{KBr}, \mathrm{cm}^{-1}\right)$ : 3371(s), 3310(s), 3201(s), 2216(vs), 1683(vs), 1624(s), 1592(vs), 1574(s), 1428(s), 1412(s), 1319(m-s), 1304(m-s), 1268(m), 1218(w), 1179(w), 1163(w), 1118(m), 1054(m), 1023(m), 982(vw), 903(w), 823(w), 784(m), 751(s), 655(s), 643(s), 619(s), 607(m), 518(w-m). NMR: $\delta\left({ }^{1} \mathrm{H}\right)$ $\left[\delta\left({ }^{13} \mathrm{C}\right)\right](\mathrm{ppm}):[\mathrm{C} 2]$ [148.9 br]; H3[C3] 8.13d [122.2]; $\mathrm{H} 4[\mathrm{C} 4]$ 8.05t [138.4]; H5[C5] 7.65t [127.0]; H6[C6] 8.64d [148.5]; $\mathrm{NH}_{2} 8.37 \mathrm{br}, 7.93$ br; $\mathrm{C}=\mathrm{O}$ [166.0]; ZnNCOO [125.3 br].

\section{2. 3. Preparation of $\left[\mathrm{Cd}(\mathrm{NCO})_{2}(\text { pia })\right]_{n}(2)$}

Used: $\mathrm{Cd}\left(\mathrm{NO}_{3}\right)_{2} \cdot 4 \mathrm{H}_{2} \mathrm{O}(0.31 \mathrm{~g} ; 1 \mathrm{mmol})$, picolinamide $(0.24 \mathrm{~g} ; 2 \mathrm{mmol})$, sodium cyanate $(0.13 \mathrm{~g} ; 2 \mathrm{mmol})$. Yield: $59 \%(0.19 \mathrm{~g} ; 0.59 \mathrm{mmol})$. Anal. Calc. for $\mathrm{C}_{8} \mathrm{H}_{6} \mathrm{Cd}-$ $\mathrm{N}_{4} \mathrm{O}_{3}: \mathrm{C}, 30.16 ; \mathrm{H}, 1.90 ; \mathrm{N}, 17.59$. Found: C, 30.26; H, 2.07; N, 17.63\%. FT-IR (Fig. S2) $\left(\mathrm{KBr}, \mathrm{cm}^{-1}\right)$ : 3433(vs), 3299(s), 3206(s), 2203(vs), 2166(vs), 1679(vs), 1651(vs), 1588(vs), 1571(vs), 1484(m), 1423(vs), 1348(m), 1307(s), 1266(m), 1177(w-m), 1161(w-m), 1115(m), 1053(m), 1017(s), 982(vw), 905(vw-w), 858(w), 822(w-m), 759(s), 751(s), 656(s-vs), 639(s), 626(s), 550(s), 504(m). NMR: $\delta\left({ }^{1} \mathrm{H}\right)\left[\delta\left({ }^{13} \mathrm{C}\right)\right](\mathrm{ppm}):[\mathrm{C} 2][149.9 \mathrm{br}] ; \mathrm{H} 3[\mathrm{C} 3]$ 8.07d [121.9]; H4[C4] 8.01tm [137.8]; H5[C5] 7.61tm [126.5]; H6[C6] 8.64dm [148.4]; $\mathrm{NH}_{2} 8.17 \mathrm{br}, 7.71$ br; $\mathrm{C}=\mathrm{O}$ [165.9]; Cd-NCEO [127.2 br].

\section{2. 4. Preparation of $\left[\mathrm{Zn}\left(\mathrm{N}_{3}\right)_{2}(\mathrm{pia})_{2}\right]$ (3)}

Used: $\mathrm{Zn}\left(\mathrm{NO}_{3}\right)_{2} \cdot 6 \mathrm{H}_{2} \mathrm{O}(0.30 \mathrm{~g} ; 1 \mathrm{mmol})$, picolinamide $(0.24 \mathrm{~g} ; 2 \mathrm{mmol})$, sodium azide $(0.13 \mathrm{~g} ; 2 \mathrm{mmol})$. Yield: $43 \%$ (0.17 g; $0.43 \mathrm{mmol}$ ). Anal. Calc. for $\mathrm{C}_{12} \mathrm{H}_{12} \mathrm{ZnN}_{10} \mathrm{O}_{2}$ : C, 36.61 H, 3.07 N, 35.59. Found: C, 36.87; H, 3.93; N, $36.02 \%$. FT-IR (Fig. S3) (KBr, cm $\left.{ }^{-1}\right): 3566(\mathrm{vs}), 3419$ (vs), 2166(vs), 2095(vs), 1675(s), 1623(m), 1558(s), 1506(s), 1384(s-vs), 1340(s-vs), 1241(w), 1200(vw-w), 1048(w$\mathrm{m}), 939(\mathrm{w}), 823(\mathrm{~m}), 695(\mathrm{vs}), 668(\mathrm{vs}), 628(\mathrm{~s}) . \mathrm{NMR}: \delta\left({ }^{1} \mathrm{H}\right)$ $\left[\delta\left({ }^{13} \mathrm{C}\right)\right](\mathrm{ppm}):[\mathrm{C} 2][147.3 \mathrm{br}] ; \mathrm{H} 3[\mathrm{C} 3]$ 8.24d [122.7]; H4[C4] 8.14t [139.3]; H5[C5] 7.74t [127.4]; H6[C6] 8.68d [148.6]; $\mathrm{NH}_{2} 8.55 \mathrm{br}, 8.12$ br; $\mathrm{C}=\mathrm{O}$ [166.0].

\section{2. 5. Preparation of $\left[\mathrm{Cd}\left(\mathrm{N}_{3}\right)_{2}(\mathrm{pia})\right] n \cdot n \mathrm{H}_{2} \mathrm{O}$ (4)}

Used: $\mathrm{Cd}\left(\mathrm{NO}_{3}\right)_{2} \cdot 4 \mathrm{H}_{2} \mathrm{O}(0.31 \mathrm{~g} ; 1 \mathrm{mmol})$, picolinamide $(0.24 \mathrm{~g} ; 2 \mathrm{mmol})$, sodium azide $(0.13 \mathrm{~g} ; 2 \mathrm{mmol})$. Yield: $59 \%(0.19 \mathrm{~g} ; 0.59 \mathrm{mmol})$. Anal. Calc. for $\mathrm{C}_{6} \mathrm{H}_{8} \mathrm{CdN}_{8} \mathrm{O}_{2}: \mathrm{C}$, 21.41; H, 2.39; N, 33.29. Found: C, 22.45; H, 1.81; N, 33.44\%. FT-IR (Fig. S4) (KBr, cm $\left.{ }^{-1}\right): 3420(\mathrm{~s}), 3294(\mathrm{~s})$, 3259(s), 2056(vs), 1670(s-vs), 1650(vs), 1604(s), 1586(s), 1570(s), 1484(w-m), 1422(s), 1330(m-s), 1306(m), 1282(m), 1222(w), 1176(m), 1120(w), 1084(w), 1052(w), 1016(w$\mathrm{m}), 820(\mathrm{w}), 776(\mathrm{~m}), 758(\mathrm{~s}), 730(\mathrm{w}), 668(\mathrm{w}), 652(\mathrm{~m})$, 638(w-m), 608(w-m), 552(m), 502(w). NMR: $\delta\left({ }^{1} \mathrm{H}\right)$ [ $\left.\delta\left({ }^{13} \mathrm{C}\right)\right](\mathrm{ppm}):[\mathrm{C} 2]$ [149.9]; H3[C3] 8.16d [122.9]; H4[C4] 8.05t [139.3]; H5[C5] 7.67tm [127.7]; H6[C6] 8.63d [149.1]; $\mathrm{NH}_{2} 8.55 \mathrm{br}, 8.12$ br; $\mathrm{C}=\mathrm{O}$ [166.4].

Abbreviations: br broad signal, d dublet, dm doublet of multiplets, $t$ triplet, tm triplet of multiplets.

Caution! The azido and cyanato complexes are potentially explosive. Therefore, they should be prepared in small quantities and handled with care.

\section{3. X-ray structural Analysis}

General and crystal data, and summary of intensity data collection and structure refinement for compounds $\mathbf{1}$ and $\mathbf{3}$ are given in Table 1. Single crystals were mounted in a random orientation on a glass fibre. Data collections were carried out on an Oxford Diffraction Xcalibur fourcircle kappa geometry single-crystal diffractometer with Sapphire 3 CCD detector, using a graphite monochromated $\operatorname{MoK\alpha }(\lambda=0.71073 \AA)$ radiation, and applying the CrysAlisPro Software system ${ }^{18}$ at 296 K. The crystal-detector distance was $60 \mathrm{~mm}$. Data reduction, including ab- 
sorption correction, was done by CrysAlis RED program. ${ }^{18}$ The structures were solved by direct methods implemented in the SHELXS-97 program. ${ }^{19}$ The coordinates and the anisotropic thermal parameters for all non-hydrogen atoms were refined by full-matrix least-squares methods based on $F^{2}$ using the SHELXL-97 program. ${ }^{19}$ The aromatic hydrogen atoms were generated geometrically using the riding model with the isotropic factor set at $1.2 U_{e q}$ of the parent atom. The amide hydrogen atoms were placed in the positions indicated by difference electrondensity maps and in $\mathbf{1}$ their positions were allowed to refine together with individual isotropic displacement para- meters, while in $\mathbf{3}$ they were constrained to ride on their parent $\mathrm{N}$ atom at distance $0.86 \AA$. Graphical work has been performed by ORTEP-3 for Windows ${ }^{20}$ and Mercury 1.4.2. ${ }^{21}$ The thermal ellipsoids were drawn at the $50 \%$ probability level.

\section{4. NMR Measurements and Chemical Shift Calculations}

All NMR measurements were performed on a Bruker DRX-500 Avance spectrometer equipped with a $5 \mathrm{~mm}$ triple broadband inverse probe (TBI) with a $\mathrm{z}$-gradient

Table 1. Crystal data and structure refinement for complexes $\mathbf{1}$ and $\mathbf{3}$.

\begin{tabular}{|c|c|c|}
\hline Compounds & $\begin{array}{c}{\left[\mathrm{Zn}(\mathrm{NCO})_{2}(\mathrm{pia})_{2}\right]} \\
(1)\end{array}$ & $\begin{array}{c}{\left[\mathrm{Zn}\left(\mathrm{N}_{3}\right)_{2}(\text { pia })_{2}\right]} \\
(3)\end{array}$ \\
\hline Empirical formula & $\mathrm{C}_{14} \mathrm{H}_{12} \mathrm{Zn} \mathrm{N}_{6} \mathrm{O}_{4}$ & $\mathrm{C}_{12} \mathrm{H}_{12} \mathrm{Zn} \mathrm{N}_{10} \mathrm{O}_{2}$ \\
\hline Formula weight & 393.69 & 393.71 \\
\hline Color and habit & colourless, block & colourless, block \\
\hline Crystal system, space group & Triclinic, $P 1$ & Orthorombic, Pna $2_{1}$ \\
\hline Crystal dimensions / mm & $0.26 \times 0.33 \times 0.47$ & $0.27 \times 0.54 \times 0.59$ \\
\hline \multicolumn{3}{|l|}{ Unit cell parameters: } \\
\hline$a / \AA$ & $6.7675(2)$ & 12.6741(3) \\
\hline$b / \AA$ & $8.8083(3)$ & $10.2571(3)$ \\
\hline$c / \AA$ & 13.9214(4) & $11.89720(3)$ \\
\hline$\alpha / \circ$ & $78.832(3)$ & 90 \\
\hline$\beta /{ }^{\circ}$ & $88.166(4)$ & 90 \\
\hline$\gamma /{ }^{\circ}$ & $80.833(3)$ & 90 \\
\hline$V / \AA^{3}$ & $803.74(4)$ & $1556.53(7)$ \\
\hline$Z$ & 2 & 4 \\
\hline$D_{\text {calc }} / \mathrm{g} \mathrm{cm}^{-3}$ & 1.627 & 1.680 \\
\hline$\mu / \mathrm{mm}^{-1}$ & 1.562 & 1.604 \\
\hline$\theta$ range for the data collection $/^{\circ}$ & $4.04-27.00$ & $3.96-30.00$ \\
\hline$h, k, l$ range & $-8: 8,-11: 11,-17: 17$ & $-17: 16,-13: 14,-16: 16$ \\
\hline Scan type & $\omega$ & $\omega$ \\
\hline$F(000)$ & 400 & 800 \\
\hline No. reflections collected & 9791 & 11628 \\
\hline No. independent reflections & 3484 & 4356 \\
\hline \multicolumn{3}{|l|}{ No. observed reflections, } \\
\hline$I \geq 2 \sigma(I)$ & 3123 & 3527 \\
\hline No. refined parameters & 242 & 243 \\
\hline$R^{a}, w R^{b}[I \geq 2 \sigma(I)]$ & $0.0251,0.0667$ & $0.0312,0.0736$ \\
\hline$R, w R$ (all data) & $0.0297,0.0692$ & $0.0429,0.0829$ \\
\hline$g_{1}, g_{2}$ in $w^{c}$ & $0.0384,0.2809$ & $0.0536,0.1086$ \\
\hline Goodness of fit on $F^{2}, S^{\mathrm{d}}$ & 1.035 & 1.015 \\
\hline \multicolumn{3}{|l|}{ Max., min. electron density / } \\
\hline Maximum $\Delta \sigma$ & $<0.001$ & $<0.001$ \\
\hline Range of transmission factors min, max & $0.545,0.666$ & $0.412,0.645$ \\
\hline Extinction coefficient & none & none \\
\hline
\end{tabular}

$$
\begin{aligned}
& { }^{\mathrm{a}} R=\sum|| F_{o}|-| F_{c}|| \Sigma\left|F_{o}\right| \\
& { }^{\mathrm{b}} w R=\left[\sum\left(F_{o}^{2}-F_{c}^{2}\right)^{2} / \sum w\left(F_{o}^{2}\right)^{2}\right]^{1 / 2} \\
& { }^{\mathrm{c}} w=1 /\left[\sigma^{2}\left(F_{o}^{2}\right)+\left[\left(g_{1} P\right)^{2}+g_{2} P \rrbracket \text { where } P=\left(F_{o}^{2}+2 F_{c}^{2}\right) / 3\right.\right. \\
& { }^{\mathrm{d}} S=\sum\left[w\left(F_{o}^{2}-F_{c}^{2}\right)^{2} /\left(N_{o b s}-N_{\text {param }}\right)\right]^{1 / 2}
\end{aligned}
$$


coil. The spectra were acquired in $\mathrm{dmso}_{6} \mathrm{~d}_{6}$ solution. Solvent signals were used as secondary references assuming $\delta\left({ }^{1} \mathrm{H}\right)=2.49 \mathrm{ppm}$ and $\delta\left({ }^{13} \mathrm{C}\right)=39.5 \mathrm{ppm}$ with respect to TMS signal (0 ppm). Typically, ${ }^{1} \mathrm{H}$ NMR, ${ }^{13} \mathrm{C}$ NMR, ${ }^{1} \mathrm{H},{ }^{1} \mathrm{H}$ COSY and ${ }^{13} \mathrm{C},{ }^{1} \mathrm{H}$ HSQC spectra were acquired in order to identify all signals. Routine parameter sets were applied for the measurements. In addition, the GIAO NMR chemical shift calculations were performed for $\mathrm{Zn}(\mathrm{NCO})_{2}(\mathrm{pia})_{2}$; calculated ${ }^{1} \mathrm{H}$ and ${ }^{13} \mathrm{C}$ chemical shifts, although slightly different from experimental values, allowed to identify signal orders. The calculations were performed at the B3LYP/[6-31G(2d), LANL2DZ] (geometry optimization) and B3PW91/[6-311G++(2d,p), LANL2DZ] (GIAO NMR calculations) assuming isolated molecule. The shielding scales were converted to chemical shift scales applying reference shielding of 31.8821 and $182.4656 \mathrm{ppm}^{\circ}{ }^{1}{ }^{1} \mathrm{H}$ and ${ }^{13} \mathrm{C}$ in TMS, respectively. All calculations were performed with the Gaussian 09 package. ${ }^{22}$ Compound numbering scheme used in NMR account, as well as computed chemical shifts are presented in Scheme 1.
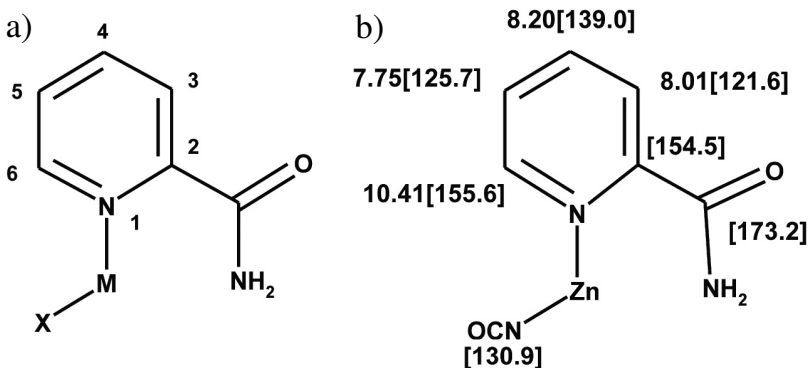

Scheme 1. Compound numbering scheme (a) and computed ${ }^{1} \mathrm{H}\left[{ }^{13} \mathrm{C}\right]$ NMR chemical shifts (b). See experimental section for details. Note that two numbering schemes (NMR and crystallographic sections) are applied to simplify the comparison of reported and literature data.

\section{Results and Discussion}

The complexes 1-4 were obtained in situ from an aqueous solutions of all reagents in a molar ratio $1: 2: 2$ at room temperature. Only the single crystals of zinc compounds $\mathbf{1}$ and $\mathbf{3}$ were of suitable quality for the X-ray experiment, allowing structure determination and ensuring a quality refinement. Unfortunately, the crystals of compounds $\mathbf{2}$ and $\mathbf{4}$ were of poor crystallinity preventing a successful refinement. Yet, the structure of $\mathbf{2}$ is determined in the triclinic space group $P 1$ revealing a neutral polymeric coordination compound in which cadmium atoms are doubly bridged with two cyanate- $N$ ions in an end-on mode thus forming 1D endless chains along the $a$ axis.

\section{1. Structure Descriptions}

The crystals of both $\mathbf{1}$ and $\mathbf{3}$ were grown by slow evaporation of the reaction mixtures under ambient conditions in a period from two days to one week. Selected bond distances, angles and details on hydrogen bond geometry are presented in Tables 2 and 3. The molecular structures are shown as ORTEP-3 drawings in Figs 1a and 2a.

Table 2. Selected bond distances $(\AA)$ and angles $\left(^{\circ}\right)$ for complexes 1 and 3.

\begin{tabular}{|c|c|c|c|}
\hline \multicolumn{4}{|c|}{ Complex 1} \\
\hline $\mathrm{Zn} 1-\mathrm{O} 3$ & $2.362(1)$ & $\mathrm{O} 3-\mathrm{Zn} 1-\mathrm{O} 4$ & $85.69(5)$ \\
\hline $\mathrm{Zn} 1-\mathrm{O} 4$ & $2.263(1)$ & O3-Zn1-N1 & $168.63(6)$ \\
\hline $\mathrm{Zn} 1-\mathrm{N} 1$ & $2.040(2)$ & $\mathrm{O} 3-\mathrm{Zn} 1-\mathrm{N} 2$ & $89.68(7)$ \\
\hline $\mathrm{Zn} 1-\mathrm{N} 3$ & $2.032(2)$ & $\mathrm{O} 3-\mathrm{Zn} 1-\mathrm{N} 3$ & $72.64(5)$ \\
\hline Zn1-N5 & $2.124(1)$ & $\mathrm{O} 3-\mathrm{Zn} 1-\mathrm{N} 5$ & $88.34(5)$ \\
\hline \multirow[t]{10}{*}{ Zn1-N7 } & $2.116(2)$ & $\mathrm{O} 4-\mathrm{Zn} 1-\mathrm{N} 1$ & $87.83(6)$ \\
\hline & & $\mathrm{O} 4-\mathrm{Zn} 1-\mathrm{N} 2$ & $171.46(7)$ \\
\hline & & $\mathrm{O} 4-\mathrm{Zn} 1-\mathrm{N} 3$ & $85.39(5)$ \\
\hline & & $\mathrm{O} 4-\mathrm{Zn} 1-\mathrm{N} 5$ & $74.42(5)$ \\
\hline & & $\mathrm{N} 1-\mathrm{Zn} 1-\mathrm{N} 2$ & $97.86(8)$ \\
\hline & & $\mathrm{N} 1-\mathrm{Zn} 1-\mathrm{N} 3$ & $97.55(7)$ \\
\hline & & N1-Zn1-N5 & $98.91(7)$ \\
\hline & & $\mathrm{N} 2-\mathrm{Zn} 1-\mathrm{N} 3$ & $100.07(7)$ \\
\hline & & N2-Zn1-N5 & $98.32(7)$ \\
\hline & & $\mathrm{N} 3-\mathrm{Zn} 1-\mathrm{N} 5$ & $153.31(6)$ \\
\hline \multicolumn{4}{|c|}{ Complex 3} \\
\hline $\mathrm{Zn} 1-\mathrm{O} 1$ & $2.193(1)$ & $\mathrm{O} 1-\mathrm{Zn} 1-\mathrm{O} 2$ & $88.2(1)$ \\
\hline $\mathrm{Zn} 1-\mathrm{O} 2$ & $2.194(3)$ & $\mathrm{O} 1-\mathrm{Zn} 1-\mathrm{N} 1$ & $74.7(1)$ \\
\hline $\mathrm{Zn} 1-\mathrm{N} 1$ & $2.165(4)$ & $\mathrm{O} 1-\mathrm{Zn} 1-\mathrm{N} 3$ & $89.6(1)$ \\
\hline $\mathrm{Zn} 1-\mathrm{N} 3$ & $2.164(4)$ & O1-Zn1-N5 & $163.8(2)$ \\
\hline Zn1-N5 & $2.096(3)$ & $\mathrm{O} 1-\mathrm{Zn} 1-\mathrm{N} 8$ & $90.3(1)$ \\
\hline \multirow[t]{9}{*}{ Zn1-N8 } & $2.070(3)$ & $\mathrm{O} 2-\mathrm{Zn} 1-\mathrm{N} 3$ & $74.3(1)$ \\
\hline & & $\mathrm{O} 2-\mathrm{Zn} 1-\mathrm{N} 5$ & $94.4(1)$ \\
\hline & & $\mathrm{O} 2-\mathrm{Zn} 1-\mathrm{N} 8$ & $163.4(2)$ \\
\hline & & $\mathrm{N} 1-\mathrm{Zn} 1-\mathrm{N} 3$ & $155.6(2)$ \\
\hline & & N1-Zn1-N5 & $89.5(2)$ \\
\hline & & N1-Zn1-N8 & $109.6(2)$ \\
\hline & & $\mathrm{N} 3-\mathrm{Zn} 1-\mathrm{N} 5$ & $106.5(2)$ \\
\hline & & N3-Zn1-N8 & $89.2(2)$ \\
\hline & & N5-Zn1-N8 & $91.7(1)$ \\
\hline
\end{tabular}

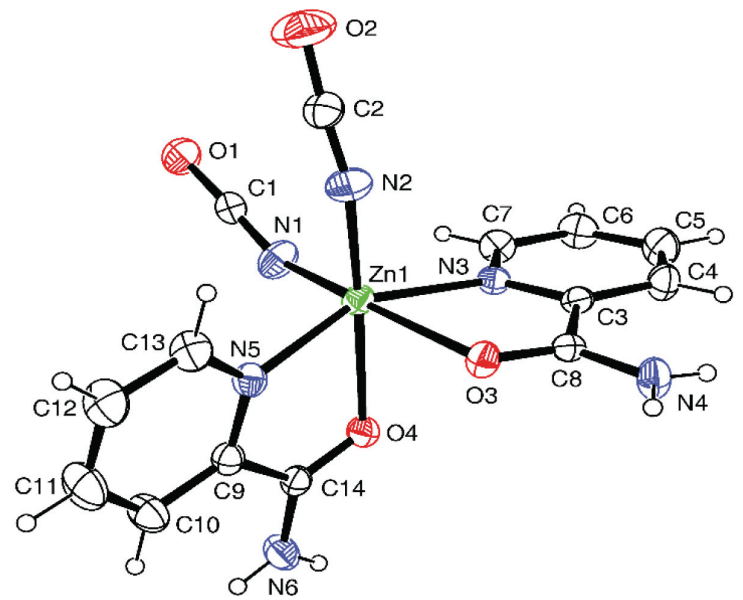

Figure 1a. Molecular structure of $\mathbf{1}$ with the atom numbering scheme. 
The cyanato complex of zinc with picolinamide (1) crystallizes in the triclinic space group $P \overline{1}$ with the zinc ion in a general position. The crystal structure of $\mathbf{1}$ comprises neutral mononuclear complex units where zinc ion is octahedrally coordinated by two cis-oriented picolinamide and cyanate ligands. The picolinamide, having the amide group in the $o$-position to the endocyclic nitrogen atom, binds to the metal core in its usually observed $\mathrm{N}, \mathrm{O}$ chelating mode, while cyanate coordinates via its nitrogen atom (Fig. 1a), thus a distorted octahedral coordination sphere around the zinc ion is achieved through four nitrogen and two oxygen atoms. All the coordination bond distances and angles (Table 2) are in accordance with the reported ones for the related structures..$^{9-16 ; 23}$

Although no significant conformational difference between the two picolinamide ligands were observed

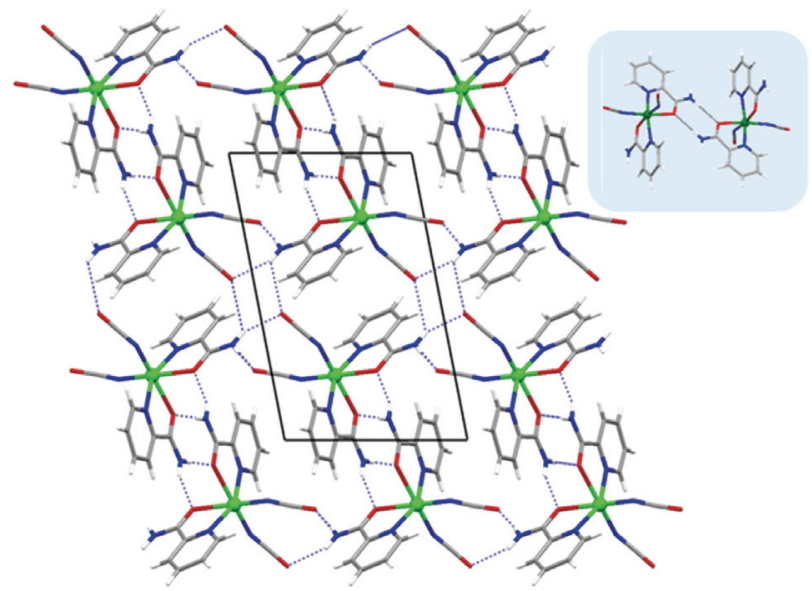

Figure 1b. Crystal packing of $\mathbf{1}$ viewed down the $a$ axis indicating hydrogen bonding interactions as dashed lines. The inset points at typical head-to-head amide synthon observed in the crystal structure of 1 . their engagement in supramolecular interactions is considerably different (Fig. 1b). The carboxamide moiety of the pia ligand defined by the atoms N3/N4/O3/C3-C 8 participates in the formation of the amide head-to-head motifs (Table 3), typically observed in the amide structures (Scheme 2a). The amide moiety belonging to the other, symmetrically independent pia ligand (N5/N6/ O4/C9-C14) does not participate in the formation of the common supramolecular amide ring structures, but instead the nitrogen atom donates both of its hydrogens in hydrogen bonds to two cyanate oxygen atoms from two neighbouring molecules thus extending the supramolecular network into 3D (Table 3). Additionally, the oxygen atom is involved in an $\mathrm{N}-\mathrm{H} \cdots \mathrm{O}$ interaction, accepting the anti-amide hydrogen atom that remains after the formation of the amide-amide dimers giving rise to the overall stabilization of the crystal structure. Interestingly, one of the cyanate oxygen atoms acts as a bifuracated acceptor and accepts two amide hydrogens forming centrosymmetrical tetrameric $\mathrm{R}_{2}^{2}(4)$ motifs (Scheme $2 \mathrm{~d}){ }^{24}$ Furthermore, the crystal structure is additionally stabilized by the off-set $\pi-\pi$ interactions involving two symmetrically related pyridine rings (N3/C3-C8) from two adjacent molecules (Table 4).

Interestingly, the only pseudohalide metal complex with picolinamide reported so far with the observed amide head-to-head motifs was one of the two thiocyanate zinc complexes. ${ }^{15}$ As the data on the pseudohalide complexes are scarce so far, it is early to draw any conclusion.

The azido complex of zinc with picolinamide (3) crystallizes in the orthorhombic space group $P n a 2_{1}$, with zinc ion located in a general position. Here again, the crystal structure is composed of neutral complex units in which the zinc ion is coordinated by two cis-related picolinamide and azide ligands. The picolinamide ligands are, here as well, bound to the metal centre through its

Table 3. Hydrogen bonds $\left(\AA\right.$ and $\left.^{\circ}\right)$ for compounds $\mathbf{1}$ and $\mathbf{3}$.

\begin{tabular}{|c|c|c|c|c|c|}
\hline D-H $\cdots A$ & D-H & 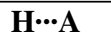 & $\mathbf{D} \cdots \mathbf{A}$ & $\angle \mathrm{DHA}$ & Symmetry code \\
\hline \multicolumn{6}{|l|}{ Compound 1} \\
\hline N4-H14N …O3 & $0.90(3)$ & $2.08(3)$ & $2.969(2)$ & $176(2)$ & $2-x, 1-y, 2-z$ \\
\hline N6-H16N…O2 & $0.85(3)$ & $2.05(3)$ & $2.889(3)$ & $170(2)$ & $-1+x, 1+y, z$ \\
\hline $\mathrm{N} 4-\mathrm{H} 24 \mathrm{~N} \cdots \mathrm{O} 4$ & $0.79(3)$ & $2.45(3)$ & $3.182(2)$ & $156(3)$ & $1-x, 1-y, 2-z$ \\
\hline 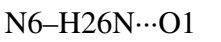 & $0.82(3)$ & $2.14(3)$ & $2.920(3)$ & $157(3)$ & $x, 1+y, z$ \\
\hline $\mathrm{C} 4-\mathrm{H} 4 \cdots \mathrm{O} 4$ & 0.93 & 2.42 & $3.192(3)$ & 140 & $1-x, 1-y, 2-z$ \\
\hline \multicolumn{6}{|l|}{ Compound 3} \\
\hline $\mathrm{N} 2-\mathrm{H} 12 \mathrm{~N} \cdots \mathrm{N} 7$ & $0.85(8)$ & $2.33(4)$ & $3.167(6)$ & $167(4)$ & $1 / 2-x, 1 / 2+y, 1 / 2+z$ \\
\hline N4-H14N‥N7 & $0.84(5)$ & $2.24(5)$ & $3.018(6)$ & $154(5)$ & $x-1 / 2,1 / 2-y, z$ \\
\hline $\mathrm{N} 2-\mathrm{H} 22 \mathrm{~N} \cdots \mathrm{N} 5$ & $0.85(4)$ & $2.50(4)$ & $3.329(5)$ & $166(4)$ & $x-1 / 2,3 / 2-y, z$ \\
\hline N4-H24N ‥N10 & $0.87(4)$ & $2.13(4)$ & $2.993(7)$ & $174(5)$ & $1 / 2-x, y-1 / 2, z-1 / 2$ \\
\hline $\mathrm{C} 2-\mathrm{H} 2 \cdots \mathrm{N} 7$ & 0.93 & 2.41 & $3.333(6)$ & 174 & $1 / 2-x, 1 / 2+y, 1 / 2+z$ \\
\hline 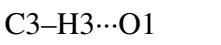 & 0.93 & 2.58 & $3.226(5)$ & 127 & $1 / 2-x, y-1 / 2,1 / 2+z$ \\
\hline C5-H5 ‥N5 & 0.93 & 2.51 & $3.075(6)$ & 120 & $x, y, z$ \\
\hline 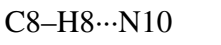 & 0.93 & 2.39 & $3.305(6)$ & 168 & $1 / 2-x, y-1 / 2, z-1 / 2$ \\
\hline C10-H10 N10 & 0.93 & 2.49 & $3.314(6)$ & 148 & $1-x, 2-y, z-1 / 2$ \\
\hline C11-H11№ & 0.93 & 2.52 & $3.065(6)$ & 117 & $x, y, z$ \\
\hline
\end{tabular}


Table 4. $\pi-\pi$ interactions $\left(\AA\right.$ and $\left.^{\circ}\right)$

\begin{tabular}{lcccc}
\hline $\mathbf{R}(i) \rightarrow \mathbf{R}(j)$ & $\mathbf{C g}(i) \cdots \mathbf{C g}(j)$ & $\boldsymbol{\alpha}^{\mathbf{a}}$ & $\boldsymbol{\beta}^{\mathbf{b}}$ & $\mathbf{C g}(i) \cdots \operatorname{plane}[\mathbf{C g}(j)]$ \\
\hline $\mathbf{C o m p o u n d ~ 1 ~}$ & $3.852(2)$ & 7.8 & 23.0 & 3.313 \\
$\mathrm{Cg}(\mathrm{N} 3, \mathrm{C} 3 \rightarrow \mathrm{C} 7) \cdots \mathrm{Cg}(\mathrm{N} 3, \mathrm{C} 3 \rightarrow \mathrm{C} 7)^{i}$ & $3.732(1)$ & 0 & 22.4 & 3.450 \\
$\begin{array}{l}\text { Compound 3 } \\
\mathrm{Cg}(\mathrm{N} 3, \mathrm{C} 7 \rightarrow \mathrm{C} 11) \cdots \mathrm{Cg}(\mathrm{N} 1, \mathrm{C} 1 \rightarrow \mathrm{C} 5)^{i i}\end{array}$ & & & \\
\hline
\end{tabular}

(i) $=1-x,-y, 2-z$, (ii) $1 / 2-x, 1 / 2+y,-1 / 2+z$.

${ }^{\mathrm{a}} \alpha=$ angle between planes of two aromatic rings ${ }^{\mathrm{b}} \beta=$ angle between $\mathrm{Cg} \cdots \mathrm{Cg}$ line and normal to the plane of the first aromatic plane

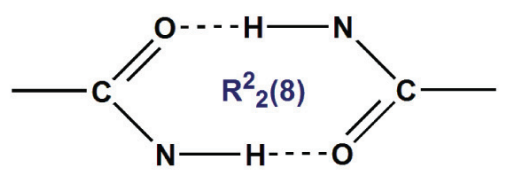

(a)

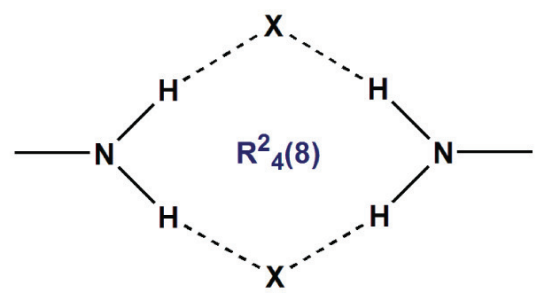

(c)<smiles>CC(=O)NC=O</smiles>

(b)

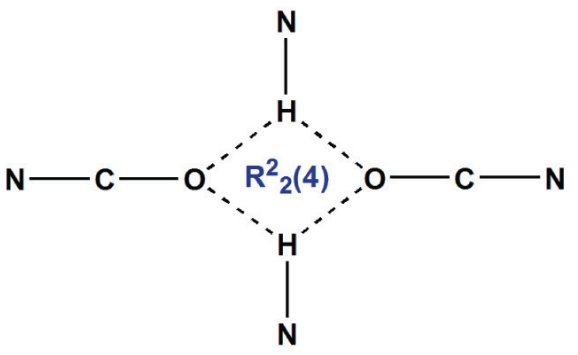

(d)

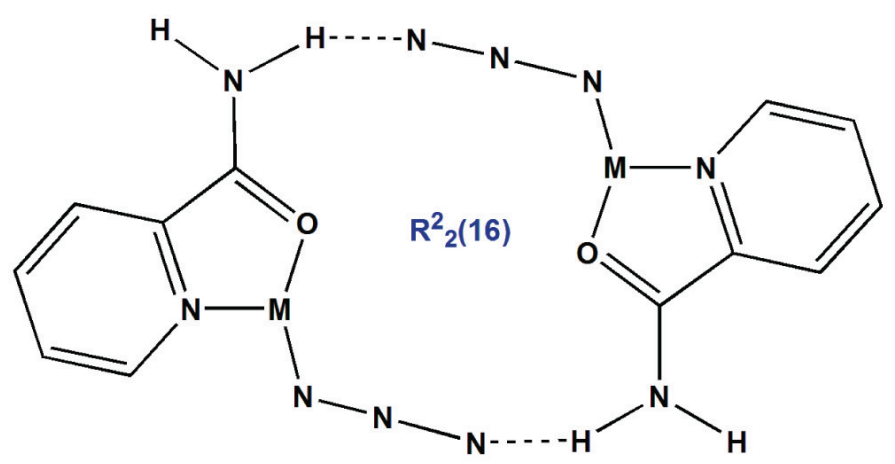

(e)

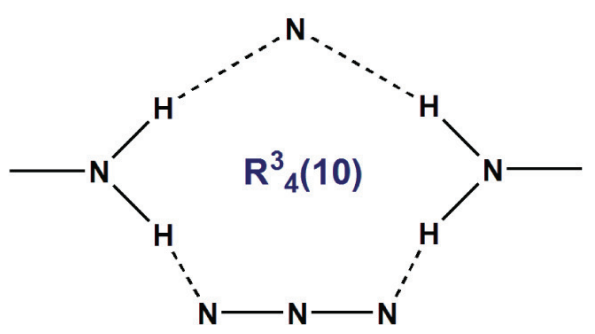

(f)

Scheme 2. Supramolecular synthons present in the picolinamide structures. ${ }^{23}$

$\mathrm{N}, \mathrm{O}$-donor set of atoms thus forming a distorted octahedron around the zinc ion via four nitrogen and two oxygen atoms (Fig. 2a).

The survey of the Cambridge Structural Database (CSD, version 1.16, 2013) reveals only seven octahedral bispicolinamide complexes with pseudohalide ions bound to metal centres; of these, there are five thiocyanato and two azido complexes. For the reported pseudohalide complexes the cis-orientation of the ligands is more pronounced; only for the nickle(II) complex ${ }^{12,14}$ both isomers are found. Therefore, the molecular structure of the complexes $\mathbf{1}$ and $\mathbf{3}$ are in accordance with literature data. 


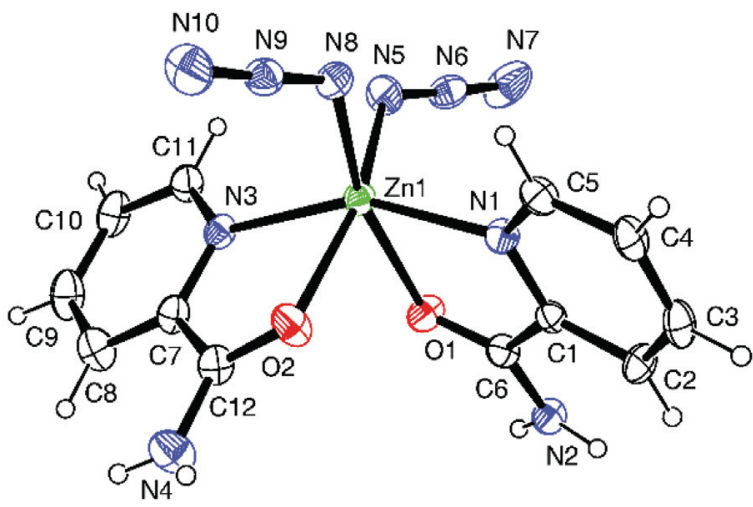

Figure 2a. Molecular structure of $\mathbf{3}$ with the atom numbering scheme.

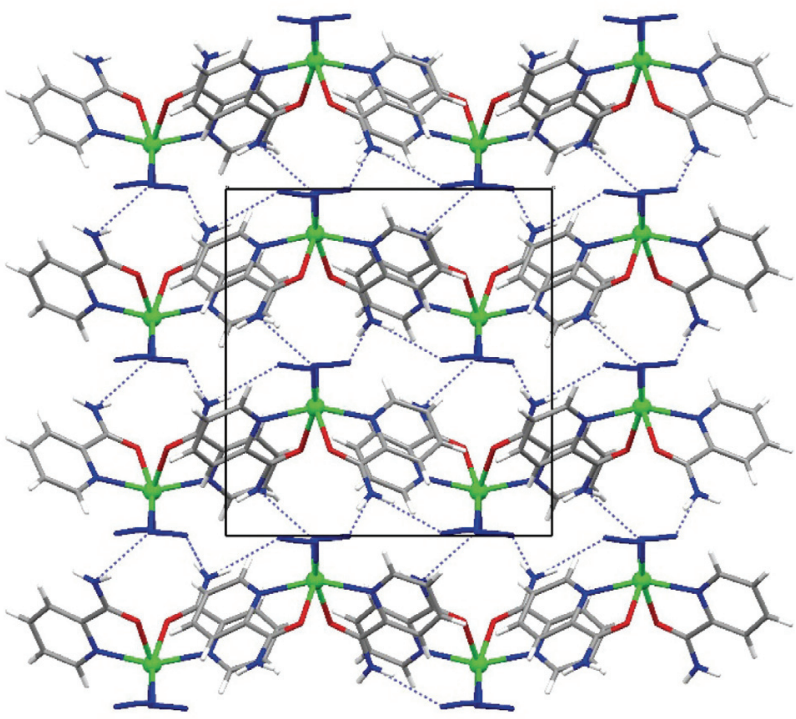

Figure 2b. Crystal packing of $\mathbf{3}$ viewed down the $b$ axis indicating hydrogen bonding interactions as dashed lines.

On analogy with other crystal structures of azide complexes with picolinamide reported so far ${ }^{12,13}$ none of the typically observed hydrogen bonding motifs are found (Scheme 2a-c), but instead, $\mathrm{R}_{2}{ }_{2}(16)$ dimers formed (Scheme 2e) between the amide group and the azide ligands are present in the complex 3 (Fig. 2b). The same motifs are observed in the cis-[Ni( $\left(\mathrm{N}_{3}\right)_{2}$ (pia) $\left.)_{2}\right]$ complex. ${ }^{12}$ Additionally, one more interesting hydrogen bonding motif is observed in 3 . It is the $\mathrm{R}_{4}^{3}(10)$ hydrogen bonding motif (Scheme 2f) that resembles the tetrameric motif $\mathrm{R}_{4}{ }_{4}(8)$ which is most frequently present in the picolinamide structures (Scheme 2c), just in this particular motif the three azide atoms replace one pseudohalide acceptor atom (Table 3).

Moreover, there are also $\pi-\pi$ stacking interactions between two pyridine rings (N1/C1-C5 and N3/C7-C11) belonging to two neighbouring molecules (Table 4) giving rise to the overall stability of the crystal strucutre.

\section{2. Spectroscopic Properties}

\section{2. 1. IR Spectra}

The absorptions assigned as $v_{\mathrm{s}}(\mathrm{CN})$ in the IR spectra of the cyanate complexes $\mathbf{1}$ and $\mathbf{2}$ are shifted towards higher wavenumbers when compared to those of the free cyanate $\left(2170 \mathrm{~cm}^{-1}\right)$. The strong $v_{\mathrm{s}}(\mathrm{CN})$ in the spectrum of $\mathbf{1}$ is observed at $2216 \mathrm{~cm}^{-1}$. The splitted $\mathrm{CN}$ stretching frequency bands observed in $\mathbf{2}\left(2203\right.$ and $\left.2166 \mathrm{~cm}^{-1}\right)$ suggest bridging coordination of the cyanate groups. ${ }^{25} \mathrm{In}$ spectrum of $\mathbf{1}$, the amide $\mathrm{C}-\mathrm{O}$ stretching frequency is observed at $1683 \mathrm{~cm}^{-1}$, indicating involvement of the amide oxygen atom into, probably more than one, hydrogen bonding. In the spectrum of $\mathbf{2}$, the splitting of the $\mathrm{C}-\mathrm{O}$ band occurred, indicating different environment of the two amide oxygen atoms. The IR spectra of the complexes $\mathbf{3}$ and $\mathbf{4}$ display the strong characteristic asymmetric stretching vibrations $v_{\mathrm{as}}\left(\mathrm{N}_{3}\right)$ of the azido ligands over the range 2166-2216 $\mathrm{cm}^{-1}$. In the spectrum of 3 , splitting of the $\mathrm{N} \equiv \mathrm{N}$ band ( 2166 and $2095 \mathrm{~cm}^{-1}$ ) is observed as a result of asymmetric azido groups while in $\mathbf{4}$ splitting is not present suggesting symmetry and $\mu_{1,3}-\mathrm{N}_{3}$ bridging coordination of the azide ligands. ${ }^{26}$

\section{2. 2. NMR Measurements}

Signal assignments were straightforward. Aromatic ${ }^{1} \mathrm{H}$ spin systems were identified by COSY experiments assuming doublet-like signals for $\mathrm{H} 2$ and $\mathrm{H} 6$, and triplet-like signals for $\mathrm{H} 3$ and $\mathrm{H} 4$. Signal order was established with the use of calculated chemical shifts. The ${ }^{13} \mathrm{C}$ signals were unambiguously identified by ${ }^{1} \mathrm{H},{ }^{13} \mathrm{C}-\mathrm{HSQC}$ and ${ }^{1} \mathrm{H}$, ${ }^{13} \mathrm{C}$ HMBC 2D experiments. The presence of two $\mathrm{NH}$ signals in each ${ }^{1} \mathrm{H}$ NMR spectrum is worth to note. Still, all data from NMR spectra corroborate with the monomeric species in DMSO solution.

\section{3. Thermal Analysis}

At ambient conditions the crystals 1, 2 and $\mathbf{4}$ possess good stability and do not show any hygroscopic effects (Figs. S5-S8). The compound 1 decomposes continuously starting form $150{ }^{\circ} \mathrm{C}$ without any pronounced mass loss step and the decomposition is followed by an endothermic process in a wide temperature range, approximately $25-500{ }^{\circ} \mathrm{C}$, with only one emphasised peak at $152{ }^{\circ} \mathrm{C}$. The analysis of the TG and DTA curves of the compound 2 shows that it is stable up to approximately $180^{\circ} \mathrm{C}$. After that temperature, it decomposes and in the temperature range $180-600{ }^{\circ} \mathrm{C}$ two endothermic peaks in the DTA curve were observed, the first small at $201{ }^{\circ} \mathrm{C}$, and second larger one at $260{ }^{\circ} \mathrm{C}$. The analysis of TG curve of compound $\mathbf{3}$ showed that its thermal decomposition starts readily by heating indicating possible hygroscopic effect and consists of three poorly separated steps. The first step is followed by small endothermic DT peak at $211^{\circ} \mathrm{C}$, it cor- 
roborates with the loss of the azide ligands (observed loss $21.50 \%$; calc. $21.35 \%$ ), and is the only step that can be resolved from the overall endothermic process occurring through the whole temperature range. The thermogravimetric data reveals that complex 4 is stable up to $160{ }^{\circ} \mathrm{C}$. Afterwards it decomposes, and the first step accompanied with the sharp endothermic DT peak at $259{ }^{\circ} \mathrm{C}$ corresponds to the loss of one water molecule and one azido ligand (found: $17.57 \%$, calculated 17.84\%). Furthermore, less resolved decomposition steps in the temperature range between 270 and $410{ }^{\circ} \mathrm{C}$ are characterized by one endothermic (small peak at $280^{\circ} \mathrm{C}$ ) and two exothermic processes (sharp peaks at 363 and $387{ }^{\circ} \mathrm{C}$ ). In the temperature range 410 to $600{ }^{\circ} \mathrm{C}$, a further exothermic process occurs with broad maximum around $530^{\circ} \mathrm{C}$. The process is followed by mass loss recorded in the TG curve, with the final residue after $600{ }^{\circ} \mathrm{C}$ of $13.66 \%$. Due to unfinished decomposition processes and sublimation of $\mathrm{Cd}$ compounds in the temperature range up to $600{ }^{\circ} \mathrm{C}$ we were not able to analyse masses of the residues for all the compounds.

\section{Conclusion}

Here we reported on four picolinamide complexes of zinc and cadmium, $\left[\mathrm{Zn}(\mathrm{NCO})_{2}(\text { pia })_{2}\right](\mathbf{1}),\left[\mathrm{Cd}(\mathrm{NCO})_{2}\right.$ (pia) $]_{n}(\mathbf{2}),\left[\mathrm{Zn}\left(\mathrm{N}_{3}\right)_{2}(\text { pia })_{2}\right](3)$ and $\left[\mathrm{Cd}\left(\mathrm{N}_{3}\right)_{2}(\text { pia })\right]_{n} \cdot \mathrm{H}_{2} \mathrm{O}$ (4). Complexes are characterized by IR and NMR spectra and TG/DTA thermal methods. The X-ray analysis revealed that the crystal structures of $\mathbf{1}$ and $\mathbf{3}$ are composed of mononuclear complex units with cis-oriented picolinamide and pseudohalide ligands, while for 2 and $\mathbf{4}$ it was concluded that they are polymeric in the solid state. NMR data are not supportive of existence of $\mathbf{2}$ and $\mathbf{4}$ in the polymeric form. In the solid state, for none of the reported zinc complexes, $\mathbf{1}$ and $\mathbf{3}$, the tetrameric $\mathrm{R}_{4}^{2}(8)$ motifs typically present in the complexes with the picolinamide-thiocyanate set of ligands are found. Instead, in the crystal structure of the compound $\mathbf{1}$ typical supramolecular amideamide dimers, described by the $\mathrm{R}_{2}^{2}(8)$ graph-set designator, are observed. Interestingly, the same supramolecular synthon was present in one of the two zinc polymorphs with the thiocyanate as a pseudohalide ligand. Unfortunately, due to the lack of data on picolinamide complexes of cadmium with azide and cyanate ligands we are not able to draw any conclusion yet. Therefore, it is worthy to emphasize the need of further research, particularly a theoretical one, in order to put some additional light to experimental data and possible inter-ligand interactions.

\section{Supplementary Data}

Crystallographic data for the structures reported in the paper have been deposited with the Cambridge Crystallographic Data Centre as supplementary publication no, CCDC 1028428-1028429. Copies of the data can be obtained free of charge at www.ccdc.cam.ac.uk/conts/ retrieving.html or from the Cambridge Crystallographic Data Centre (CCDC), 12 Union Road, Cambridge CB2 1EZ, UK; fax: +44(0)1223-336-033; or e-mail: deposit $@$ ccdc.cam.ac.uk.

\section{Acknowledgements}

This research was supported by Ministry of Science, Education and Sports of the Republic of Croatia within the scientific projects under the titles "Chemistry of metal complexes in reactions of biological importance and new materials" (No. 119-1193079-1332), within the framework of the scientific program "Ligands, complexes, proteins - synthesis and structure - properties relationship".

\section{References}

1. O. M. Yaghi, H. L. Li, C. Davis, D. Richardson, T. L. Groy, Acc. Chem. Res. 1998, 31, 474-484. http://dx.doi.org/10.1021/ar970151f

2. B. Moulton, M. J. Zaworotko, Chem. Rev. 2001, 101, 16291658. http://dx.doi.org/10.1021/cr9900432

3. B. J. Hollyday, C. A. Mirkin, Angew. Chem. Int. Ed. Engl. 2001, 40, 2022-2043. http://dx.doi.org/10.1002/1521-3773 (20010601)40:11<2022::AID-ANIE2022>3.0.CO;2-D

4. R. Matsuda, R. Kitura, S. Kitagawa, Y. Kubota, R. V. Belosludov, T. C. Kobayashi, K. Sakamoto, T. Chiba, M. Takata, Y. Kawazoe, Y. Mita, Nature 2005, 436, 238-241. http://dx.doi.org/10.1038/nature03852

5. F. Jeremias, D. Frõhlich, C. Janiak, S. K. Henninger, New J. Chem. 2014, 38, 1846-1852.

http://dx.doi.org/10.1039/c3nj01556d

6. C. Janiak, Dalton Trans. 2003, 2781-2804. http://dx.doi.org/10.1039/b305705b

7. M. C. Bernini, F. Gándara, M. Iglesias, N. Snejko, E. GGutiérez-Puebla, E. V. Brusau, G. E. Narda, M. Á. Monge, Chem. Eur. J. 2009, 15, 4896-4905.

http://dx.doi.org/10.1002/chem.200802385

8. P. M. Foster, N. Stock, A. K. Cheetham, Angew. Chem. Int. Ed. Engl. 2005, 44, 7608-7611. http://dx.doi.org/10.1002/anie.200501766

9. M. Đaković, D. Vila-Vicosa, M. J. Calhorda, Z. Popović, CrystEngComm. 2011, 13, 5863-5871; M. Đaković, D. VilaVicosa, N. A. G. Bandeirab, M. J. Calhorda, B. Kozlevčar, Z. Jagličić, Z. Popović, CrystEngComm. 2013, 15, 8074-8087. http://dx.doi.org/10.1039/c3ce41011k

10. M. Đaković, M. Vinković, S. Roca, Z. Popović, I. Vicković, D. Vikić-Topić, J. Lukač, N. Đaković, Z. Kusić, J. Coord. Chem. 2012, 65, 1017-1032. http://dx.doi.org/10.1080/00958972.2012.663912

11. M. Đaković, M. Benko, Z. Popović, J. Chem. Crystallogr. 
2011, 41, 343-348. http://dx.doi.org/10.1007/s10870-010-9885-5

12. M. Đaković, Z. Popović, Acta. Crystallogr. 2008, E64, m311-m312.

13. M. Đaković, Z. Popović, Acta Crystallogr. 2007, C63, m557-m559.

14. M. Đaković, Z. Popović, Acta Crystallogr. 2007, C63, m507-m509.

15. M. Đaković, Z. Popović, G. Giester, M. Rajić-Linarić, Polyhedron 2008, 27, 210-222. http://dx.doi.org/10.1016/j.poly.2007.09.014

16. M. Đaković, B.-M. Kukovec, Z. Popović, Transition Met. Chem. 2011, 36, 65-71. http://dx.doi.org/10.1007/s11243-010-9435-1

17. STAR ${ }^{\mathrm{e}}$ Software V.9.0., Mettler Toledo GmbH, 2006.

18. Oxford Diffraction, Version 1.171.32 Oxford Diffraction Ltd., Xcalibur CCD System, CrysAlis, 2006.

19. G. M. Sheldrick, Acta Crystallogr. 2008, A64, 112-112. http://dx.doi.org/10.1107/S0108767307043930

20. L. J. Farrugia, ORTEP-3, J. Appl. Crystallogr. 2012, 45, 849-854. http://dx.doi.org/10.1107/S0021889812029111

21. I. J. Bruno, J.C. Cole, P.R. Edgington, M.K. Kessler, C.F. Macrae, P. McCabe, J. Pearson, R. Taylor, Acta Crystallogr., 2002, B58, 389-397. http://dx.doi.org/10.1107/S0108768102003324

22. M. J. Frisch, G. W. Trucks,H. B. Schlegel, G. E. Scuseria, M. A. Robb, J. R. Cheeseman, J. A. Montgomery, T. Vreven jr.; K. N. Kudin, J. C. Burant, J. M. Millam, S. S. Iyengar, J. Tomasi, V. Barone, B. Mennucci, M. Cossi, G. Scalmani, N. Rega, G. A. Petersson, H. Nakatsuji, M. Hada, M. Ehara, K.
Toyota, R. Fukuda, J. Hasegawa, M. Ishida, T. Nakajima, Y. Honda, O. Kitao, H. Nakai, M. Klene, X. Li, J. E. Knox, H. P. Hratchian, J. B. Cross, C. Adamo, J. Jaramillo, R. Gomperts, R. E. Stratmann, O. Yazyev, A. J. Austin, R. Cammi, C. Pomelli, J. W. Ochterski, P. Y. Ayala, K. Morokuma, G. A. Voth, P. Salvador, J. J. Dannenberg, V. G. Zakrzewski, S. Dapprich, A. D. Daniels, M. C. Strain, O. Farkas, D.K. Malick, A. D. Rabuck, K. Raghavachari, J. B. Foresman, J. V. Ortiz, Q. Cui, A. G. Baboul, S. Clifford, J. Cioslowski, B. B. Stefanov, G. Liu, A. Liashenko, P. Piskorz, I. Komaromi, R. L. Martin, D. J. Fox, T. Keith, M. A. Al-Laham, C. Y. Peng, A. Nanayakkara, M. Challacombe, P. M. W. Gill, B. Johnson, W. Chen, M. W. Wong, C. Gonzalez and J. A. Pople, Gaussian 03, Revision B.5, Gaussian, Inc., Pittsburgh PA, 2003

23. H. F. Allen, Acta Crystallogr. 2002, B58, 380-388. http://dx.doi.org/10.1107/S0108768102003890

24. (a) M. C. Etter, Acc. Chem. Res., 23, 120 (1990); http://dx.doi.org/10.1021/ar00172a005

(b) J. Bernstein, R. E. Davis, L. Shimoni, N.-L. Chang, Angew. Chem., Int. Ed. Engl. 1995, 34, 1555-1573. http://dx.doi.org/10.1002/anie.199515551

25. S. Banerjee, S. Sen, S. Basak, S. Mitra, D. L. Hughes, C. Desplanches, Inorg. Chim. Acta, 2008, 361, 2707-2714. http://dx.doi.org/10.1016/j.ica.2008.01.020

26. M.A.S. Goher, F. A. Mautner, A. K. Hafez, M. A. M. AbuYoussef, C. Gspan, A. M.-A. Badr, Polyhedron, 2003, 22, 975-979.

http://dx.doi.org/10.1016/S0277-5387(03)00022-6

\section{Povzetek}

Pripravili in okarakterizirali z IR in NMR spektroskopijo ter termičnimi (TG/DTA) metodami smo štiri nove komplekse $\mathrm{Zn}$ in $\mathrm{Cd}$ s pikolinamidom (pia), $\left[\mathrm{Zn}(\mathrm{NCO})_{2}(\text { pia })_{2}\right](\mathbf{1}),\left[\mathrm{Cd}(\mathrm{NCO})_{2}(\text { pia })\right]_{n}(\mathbf{2}),\left[\mathrm{Zn}\left(\mathrm{N}_{3}\right)_{2}(\text { pia })_{2}\right](\mathbf{3})$ in $\left[\mathrm{Cd}\left(\mathrm{N}_{3}\right)_{2}(\text { pia })\right]_{n}$. $n \mathrm{H}_{2} \mathrm{O}$ (4). Rentgenska strukturna analiza na monokristalih je za spojini $\mathbf{1}$ in $\mathbf{3}$ razkrila enojedrno zgradbo z oktaedrično $\mathrm{N}_{4} \mathrm{O}_{2}$ cis-razporeditvijo donorskih atomov okrog cinkovega(II) iona. Le amid v spojini $\mathbf{1}$ je mogoče razvrstiti v skupino »head-to-head« supramolekularnih motivov (oznaka je $\mathrm{R}_{2}^{2}(8)$ ). V strukturi spojine $\mathbf{3}$ pa nismo prepoznali nobenega od značilnih strukturnih motivov za amid. Čeprav je mogoče iz IR spektrov spojin $\mathbf{2}$ in $\mathbf{4}$ sklepati na polimerno zgradbo, pa NMR spektri kažejo na enojedrno zgradbo kompleksnih zvrsti v raztopinah. 